\title{
OPTIMALISASI PELAKSANAAN REKRUTMEN BINTARA POLRI DI PROVINSI KALIMANTAN TENGAH
}

\section{OPTIMIZATION OF RECRUITMENT OF POLICE PETTY OFFICERS IN CENTRAL KALIMANTAN PROVINCE}

\section{Noviandhi Wahyu Bintoro \\ Muhamad Yusuf}

\section{Nova Riyanti}

Universitas Muhammadiyah Palangka Raya, Palangka Raya, Central Kalimantan, Indonesia

Email : riyantinv@gmail.com
Kata Kunci:

Optimalisasi

Pelaksanaan

Rekrutmen

Polri

Keywords:

Optimization implementation

Recruitment

Police

\begin{abstract}
Abstrak
Penelitian ini bertujuan untuk menganalisis faktor-faktor penghambat dari mekanisme seleksi dan pelaksanaan rekrutmen yang telah dilaksanakan pada Polda Kalimantan Tengah dalam rangka membentuk calon Bintara Polri yang profesional.

Adapun metode dalam penelitian ini berjenis deksriftif kualitatif yang bertujuan menggambarkan tentang pelaksanaan rekrutmen Bintara Polri dalam Rangka Pembentukan Sumber daya Manusia Polri yang berkualitas, bersih, transparan, akuntabel dan humanis guna mewujudkan personel Bintara Polri di Polda Kalimantan Tengah yang profesional, modern dan terpercaya. Data penelitian ini diperoleh dari hasil pengamatan langsung, wawancara, dan mengumpulkan dokumen-dokumen. Adapun informan dalam penelitian ini yaitu : Karo SDM Polda Kalteng, Kabagdalpers Biro SDM Polda Kalteng, Kasubbagdiapers Bagdalpers Biro SDM Polda Kalteng, Paur Subbagdiapers Bagdalpers Biro SDM Polda Kalteng dan para perserta yang mengikuti seleksi Bintara.

Hasil penelitian menunjukan mekanisme yang selama ini dilaksanakan dalam rekrutmen Bintara Polri Polda Kalteng sudah melalui tahapan yang ditetapkan dari Panitia Pusat/Mabes Polri namun dalam pelaksanaannya masih kurang optimal karena adanya beberapa kendala pada setiap rangkaian tahapan seleksi.
\end{abstract}

\section{Abstract}

This study aims to analyze the inhibiting factors of the selection mechanism and the implementation of recruitment that has been carried out at the Central Kalimantan Police in order to form a professional NCO candidate.

The method in this research is a qualitative descriptive type which aims to describe the implementation of the recruitment of the National Police NCO in the Context of Formation of qualified, clean, transparent, accountable and humanist National Police Human Resources in order to create professional, modern and reliable NCO personnel at the Central Kalimantan Police. The data of this research were obtained from direct observation, interviews, and collecting documents. The informants in this study were: Head of HR Department of the Central Kalimantan Police, Head of the Central Kalimantan Regional Police's HR Bureau, Head of the Central Kalimantan Regional Police's HR Bureau, Head of the Central Kalimantan Police's HR Bureau of Diapers, Paur Central Kalimantan Regional Police's HR Subdivision Paur, and the participants who took part in the NCO selection.

The results show that the mechanism that has been implemented so far in the recruitment of the Central Kalimantan Police NCO has gone through the stages set by the Central Committee/Police Headquarters but in its implementation it is still not optimal due to several obstacles in each series of selection stages. 


\section{PENDAHULUAN}

Kepolisian Negara Repubik Indonesia atau biasa disebut Polri merupakan alat negara yang berperan dalam memelihara keamanan dan ketertiban masyarakat, menegakkan hukum, serta memberikan perlindungan, pengayoman, dan pelayanan kepada masyarakat dalam rangka terpeliharanya keamanan dalam negeri. Polri memiliki beberapa misi, satu diantaranya adalah mengelola secara profesional, transparan, akuntabel dan modern seluruh sumber daya Polri guna mendukung operasional tugas Polri (Divisi Humas Polri, 2015). Salah satu upaya guna mewujudkan misi tersebut adalah sistem rekrutmem sumber daya yang tepat.

Kepolisian Republik Indonesia dalam upaya memenuhi kebutuhan personel Polri khususnya yang berpangkat Bintara, maka dilaksanakan proses seleksi Bintara Polri bertahap oleh Kapolri. Pada pelaksanaan seleksi tersebut, Kapolri mendeligasikan kewenangan kepada Kapolda dan jajaran melalui seleksi penerimaan Bintara Polri yang dilaksanakan masing - masing Kepolisian Daerah. Hal ini dilakukan untuk memenuhi standar rasio jumlah personel Polri sesuai dengan DSP (Daftar Susunan Personel) Polri seperti yang tercantum dalam peraturan Kapolri. Pelaksanaan seleksi penerimaan Brigadir Polri tersebut disesuaikan dengan berdasarkan anggaran yang ada.

Kepolisian Daerah Kalimantan Tengah atau Polda Kalteng merupakan lembaga kepolisian daerah yang memiliki tugas kepolisian, pada wilayah kerja. Polda Kalteng memiliki tugas dan tanggung jawab dibawah Kepolisian Negara Republik Indonesia yang menaungi I 3 Kabupaten dan I Kota di Provinsi Kalimantan Tengah. Pada setiap Kabupaten dan Kota terdapat instusi kepolisian yang disebut Kepolisian Resor (Polres) dan Kepolisian Resor Kota (Porlesta).

Adapun beberapa hal yang menjadi daya tarik bagi penulis untuk untuk melihat optimalisasi pelaksanaan rekrutmen pada Polda Kalimantan Tengah yakni perubahan aspek kultural yang meliputi perubahan dalam pelaksanaan manajemen sumber daya manusia, yaitu menyangkut masalah penyediaan personel atau rekrutmen Sumber Daya Manusia. Mengingat Sumber Daya manusia merupakan salah satu aspek penting dalam mewujudkan anggota Polri mandiri yang profesional,untuk mewujudkan Polri profesional melalui pendidikan dan latihan serta pembenahan, sistem pembinaan sumber daya manusia termasuk pembenahan sistem rekrutmen dan seleksi anggota. Seleksi penerimaan dalam rekrutmen personel Polri merupakan tahap yang sangat penting dalam menentukan kualitas sumber daya manusia, sistem rekrutmen dan seleksi Bintara Polri yang berlangsung selama ini, dirasakan masih belum dapat menghasilkan anggota Polri yang memiliki kualitas seperti yang diharapkan. Pada kenyataannya masih terdapat kelemahan-kelemahan di dalam sistem rekrutmen dan seleksi yang bertujuan untuk membentuk Polri yang profesional dan berkualitas.

Kalimantan Tengah yang merupakan salah satu propinsi yang sedang berkembang selalu menuntut kehadiran Sumber Daya Manusia (SDM) yang berkualitas dan terus mengikuti perkembangan peradaban. Hal ini didukung dengan terdapat banyaknya sekolah-sekolah unggulan yang menjadi peluang bagi Institusi Polri untuk dapat menjaring SDM Bintara Polri yang berkualitas di Polda Kalteng. Namun pada kenyataannya, berdasarkan hasil pelaksanaan rekrutmen Bintara Polri di Polda Kalteng pada lima tahun terakhir ini, menunjukkan bahwa masih terdapat rendahnya animo pendaftar serta terdapat peserta seleksi yang gugur dalam jumlah besar pada tiap tahapan seleksi bahkan terdapat kondisi under kuota (pada tahun tertentu) untuk Polda Kalteng pada proses rekrutmen Bintara Polri, sehingga dalam hal ini pengemban fungsi SDM khususnya Biro SDM Polda Kalteng sangat memerlukan metode rekrutmen calon Bintara Polri yang lebih berkualitas, bersih, transparan, akuntabel dan humanis, yang diharapkan dapat menarik minat para 
generasi muda Kalimantan Tengah untuk menggabungkan diri mengabdi sebagai anggota Polri.

Penelitian ini bertujuan untuk meneliti sejauh mana mekanisme seleksi dan bagaimana pelaksanaan rekrutmen yang telah dilaksanakan pada Polda Kalimantan Tengah dalam rangka membentuk calon Bintara Polri yang profesional. Permasalahan yang dimunculkan pada penelitian ini adalah pelaksanaan rekrutmen Bintara Polri dalam Rangka Pembentukan Sumber daya Manusia Polri yang berkualitas, bersih, transparan, akuntabel dan humanis guna mewujudkan personel Bintara Polri di Polda Kalimantan Tengah yang profesional, modern dan terpercaya.

\section{METODOLOGI}

Penelitian ini menggunakan pendekatan kualitatif karena fenomena yang diteliti sangat kompleks dan dinamis. Kemudian, alasan peneliti menggunakan metode penelitian kualitatif karena peneliti ingin mendeksripsikan data berupa informasi yang ditemukan dilapangan yang akan digunakan untuk menganlisis meringkas berbagai kondisi.

Adapun penelitian ini berjenis deksriftif kualitatif yang bertujuan menggambarkan tentang pelaksanaan rekrutmen Bintara Polri dalam Rangka Pembentukan Sumber daya Manusia Polri yang berkualitas, bersih, transparan, akuntabel dan humanis guna mewujudkan personel Bintara Polri di Polda Kalimantan Tengah yang profesional, modern dan terpercaya.

Data penelitian ini diperoleh dari hasil pengamatan langsung, wawancara, dan mengumpulkan dokumen-dokumen. Adapun informan dalam penelitian ini yaitu : Karo SDM Polda Kalteng, Kabagdalpers Biro SDM Polda Kalteng, Kasubbagdiapers Bagdalpers Biro SDM Polda Kalteng, Paur Subbagdiapers Bagdalpers Biro SDM Polda Kalteng dan para perserta yang mengikuti seleksi Bintara. Serta data yang dikumpulkan dalam hal ini Profile Biro Personalia Polda Kalimantan Tengah, SOP Mekanisme/prosedur rekrutmen Bintara
Polri Pada Polda Kalimantan Tengah, Data analisa dan evaluasi hasil seleksi rekrutmen Bintara Polri pada 3 tahun terakhir tahun 2018 s.d. tahun 2020 Dokumen terkait lainnya yang mendukung penelitian ini.

\section{HASIL DAN PEMBAHASAN}

\section{Pelaksanaan Rekrutmen Bintara Polri Pada Polda Kalimantan Tengah}

Pengumuman pendaftaran anggota Polri secara terpadu dengan cara mendaftar secara online melalui website www.penerimaan.polri.go.id yang selanjutnya melakukan registrasi sesuai dengan pilihan (Akpol, Bintara dan Tamtama) dan verifikasi akan dilaksanakan di panitia daerah yakni di Polda Kalimantan Tengah dan dilanjutkan dengan tahapan seleksi. Penerimaan Polisi dilaksanakan dengan prinsip BETAH (Bersih, Transparan, Akuntabel dan Humanis).

Pada awal pelaksanaannya dilakukan tahap sosialisasi ke beberapa sekolah unggulan yang ada diwilayah sekitaran Polda jajaran yang bertujuan untuk menyampaikan visi misi dari rekrutmen pro aktif ini. Dari sosialisasi ini diharapkan dapat membuka wawasan dan motivasi dari pada siswa disekolah unggulan tersebut. Selanjutnya sesuai dengan tujuan menjaring talenta-talenta terbaik maka Biro Sumber Daya Manusia Polda Kalteng khususnya Bagian Pengendalian Personel Sub Bagian Penyediaan Personel merupakan ujung tombak pelaksana kegiatan rekrutmen Bintara Polri, yang dilaksanakan secara rutin pada setiap tahunnya. Dimana kegiatan rekrutmen ini di desain terintegrasi melalui mekanisme rangkaian tahapan seleksi yang terdiri dari kegiatan sebagai berikut:

I. Sosialisasi dan Kampanye

Sosialisasi dan kampanye dilaksanakan pada Tingkat Daerah (Polda) maupun pada Tingkat Kewilayahan (Polres/Panbanrim) guna memberikan penerangan dan informasi yang dilaksanakan secara terus menerus sepanjang tahun tentang proses kegiatan rekrutmen anggota Polri disertai dengan penjelasan tata cara pendaftaran, persyaratan 
maupun tahapan seleksi guna menarik minat dan meningkatkan animo masyarakat, dengan sasaran kegiatan sosialisasi dan kampanye adalah seluruh lapisan masyarakat baik diperkotaan dan pedesaan, pemuda pemudi putra daerah setempat yang sudah lulus/tamat sekolah, pelajar SMA/MA/SMK,serta pada tempat keramaian/ berkumpulnya masyarakat. Selama terjadinya pandemi Covid-19 ini, proses sosialisasi dan kampanye dilakukan diberbagai media cetak, baliho dan media sosial untuk menjangkau semua lapisan masyarakat. Adapun media sosial yang digunakan untuk penyebaran informasi adalah whatapps, twitter, instagram,facebook dan lain-lainnya.

\section{Gambar I}

Media Sosial untuk sosialisasi

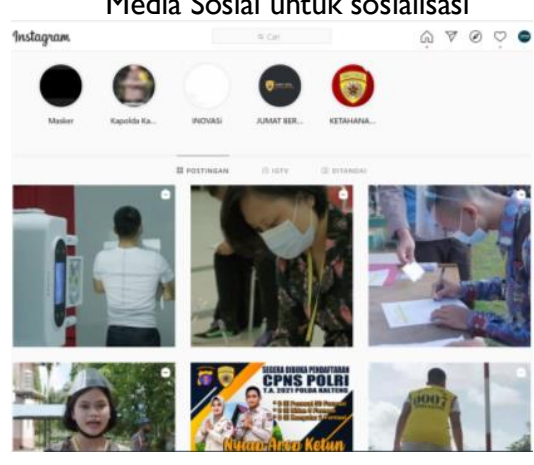

Namun muncul beberapa kendala dilapangan yang masih terjadi pada saat pelaksanaan sosialisasi dan kampanye antara lain sebagai berikut:

a) Kurangnya rasa peduli dari personel Polri untuk menyampaikan dan memberikan informasi kepada masyarakat tentang proses dan pelaksanaan rekrutmen Bintara Polri;

b) Ujung tombak dalam pelaksanaan sosialisasi dan kampanye rekrutmen Bintara Polri hanya dibebankan kepada personel SDM yang mengawaki (Subbagdiapers Bagdalpers Biro SDM Polda dan Bagsumda Polres) serta dibantu oleh bhabinkamtibmas Polres;

c) Bahan materi sosialisasi dan kampanye yang berubah-ubah terutama pada persyaratan, membuat lambatnya penyampaian informasi kepada masyarakat sehingga kegiatan sosialisasi dan kampanye seakan-akan harus menunggu Warning Order (WO) terlebih dahulu dari Panitia Pusat/Mabes Polri.

2. Pendaftaran

Proses pendaftaran dilaksanakan secara langsung oleh pendaftar dengan alamat website penerimaan anggota Polri alamat www.penerimaan.polri.go.id dan selanjutnya pendaftar membawa bukti pendaftaran online ke Polres terdekat sebagai panitia pembantu penerimaan (Panbanrim) dengan membawa persyaratan administrasi.

Adapun kendala yang dihadapi pada tahap pendaftaran online adalah kurangnya sosialisasi tata cara pendaftaran serta kurang tersedianya jaringan internet pada daerah pelosok sehingga pendaftar lebih banyak datang ke Polres untuk mendaftar secara online melalui operator pendaftaran di Polres selaku Pabanrim.

3. Tahapan Seleksi

Tahapan seleksi rekrutmen Bintara Polri di Polda Kalteng dilaksanakan pada Tingkat Polres selaku Panitia Pembantu Penerimaan (Panbanrim) dan pada Tingkat Polda selaku Panitia Daerah (Panda), tahapan seleksi yang dilaksanakan dengan mendasari ketentuan yang telah ditetapkan dari Panitia Pusat/Mabes Polri dengan menggunakan sistem gugur pada tiap tahapannya.

Seluruh Tahapan seleksi rekrutmen Bintara Polri di Polda Kalteng direkam dan ditayangkan di akun Youtube Biro SDM Polda Kalteng sebagai berikut :

Gambar 6 Youtube Biro SDM Polda Kalteng BIRO SDM POLDA KALTENG - Biro SDM Polda Katteng A-2.

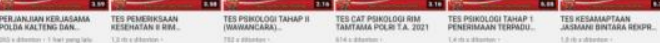

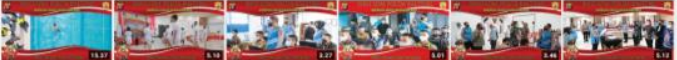


Berdasarkan gambar 6 dengan kepemilikan akun Biro SDM Polda Kalteng ini merupakan media untuk keterbukaan informasi bagi masyarakat umum melihat proses seleksi rekrutmen yang dilakukan di Biro SDM Polda Kalteng. Hal ini juga untuk mendorong kepercayaan masyarakat terhadap pelaksanaan rekrutmen Bintara Polri dalam Rangka Pembentukan Sumber daya Manusia Polri yang berkualitas, bersih, transparan, akuntabel dan humanis guna mewujudkan personel Bintara Polri di Polda Kalimantan Tengah yang profesional, modern dan terpercaya.

Namun, Permasalahan yang timbul di lapangan pada saat tahapan seleksi tersebut di atas dapat dijelaskan sebagai berikut :

a) Pada saat pemeriksaan administrasi awal dan akhir masih sering ditemukan ketidakpastian tentang pembagian tugas pemeriksaan antara Tim Pemeriksa dari Polda Kalteng dan Tim Eksternal dari outshourching (Diknas, Disdukcapil dan Dosen Akademik) antara lain pada penghitungan nilai akhir/nilai gabungan antara nilai Ujian Nasional dan nilai Ujian Sekolah, keabsahan hitungan domisili bagi pendatang maupun putra daerah, pemeriksaan tinggi dan berat badan yang tidak sama antara pengukuran pada Tingkat Panbanrim dan Tingkat Panda;

b) Pada tahap pemeriksaan kesehatan masih belum menggunakan pihak outshourching/eksternal dalam pemeriksaan maupun input data khususnya pada tahap Pemeriksaan I (satu) atau pemeriksaan luar sehingga image masyarakat bahwa pemeriksaan kesehatan kurang transparan dan terbuka;

c) Pada tahap pemeriksaan psikologi masih adanya jeda waktu dari pemeriksaan dengan koreksi (selisih satu hari), sehingga anggapan peserta dan masyarakat bahwa pemeriksaan psikologi masih belum transparan dan terbuka; d) Pada tahap uji kemampuan jasmani masih ada image masyarakat bahwa yang mampu adalah orang yang kenal dengan petugas penguji, banyak peserta yang diprotes oleh temannya sendiri dalam hal penghitungan angka hasil jasmaninya sehingga terjadi kekurangpercayaan peserta kepada tim penguji;

e) Pada tahap penelusuran mental kepribadian (PMK) masih terjadi peserta yang tidak lulus tahapan seleksi masih diminta data perorangan oleh pihak Polsek maupun dari Polres sehingga anggapan masyarakat masih kurangnya koordinasi antara panitia seleksi;

f) Pada tahap penentuan kelulusan sementara dan kelulusan akhir masih ada jeda waktu yang sangat panjang pada rekrutmen Bintara Polri sehingga dikhawatirkan adanya orang yang tidak bertanggung jawab untuk memanfaatkan situasi mencari keuntungan dalam masa jeda waktu pengumuman kelulusan akhir dimaksud.

\section{Analisa Pelaksanaan Rekrutmen Bintara Polri}

Berdasarkan hasil analisa dan evaluasi yang telah dilakukan oleh Biro SDM Poda Kalteng pada tahun 20I8,20I9,2020 khusus untuk rekrutmen penerimaan Polri yaitu seperti pada gambar data dibawah ini :

Tabel I

Perbandingan Data Rekrutmen Polda Kalteng

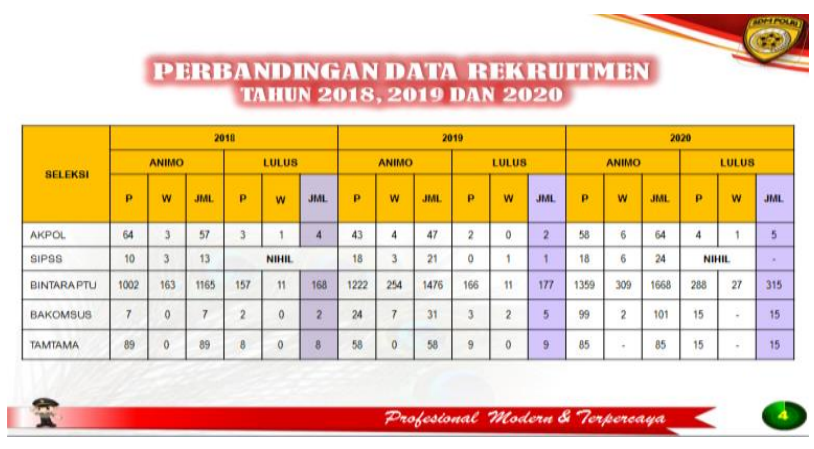

Dari hasil data tabel I diatas menunjukkan bahwa pada perbadningan rekrutmen polri di kalimantan tengah mengalami kenaikan setiap tahunnya yaitu pada tahun 2018 terus meningkat sampai pada 
tahun 2020 untuk Bintara PTU. Sedangkan data lainya animonya fluktuatif setiap tahunnya.

Tabel 2

Data Tahapan Seleksi Penerimaan Dalam Rekrutmen Bintara Polri di Polda Kalteng selama tiga tahun terakhir : TAHAPAN SELEKSI PENERIMAAN BINTARA PTU

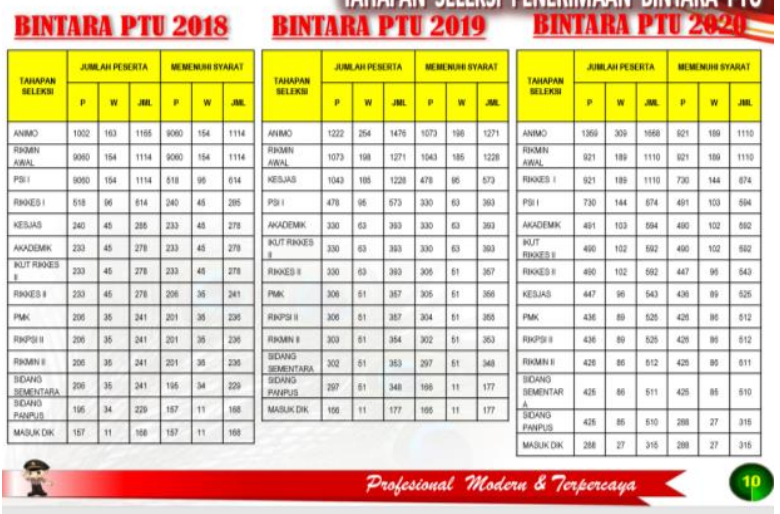

Melalui data tabel 2 data tahapan seleksi penerimaan Bintara PTU ini mendetai setiap tahapan baik dari animo yang mengikuti seleksi sampai pada keseluruhan tes yang dilakukan. Terlihat bahwa terdapat peserta seleksi yang gugur dalam jumlah besar pada tiap tahapan seleksi. Dalam 3 tahun terakhi ini terlhat pada tahapan awal dari rikmin awal ke tes lanjutannya sudah menggugurkan hampir $50 \%$ persen dari seluruh peserta artinya banyaknya animo tersebut sudah tereleminasi dengan tidak memenuhi syarat dan standar kelulusannya.

Tabel 3

Data Kelulusan Bintara Polri Kabupaten/Kota di Polda Kalteng selama tiga tahun terakhir

KEGIATAN REKRUITMEN BINTARA PTU

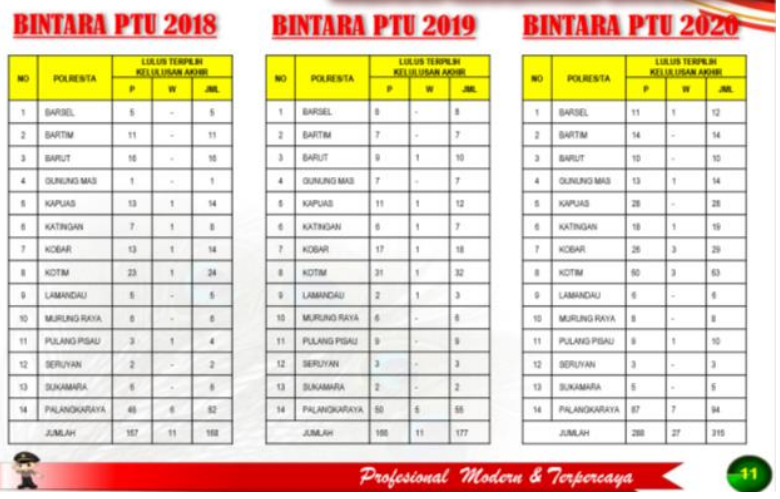

Untuk menganalisa lebih lanjut pelaksanaan rekrutmen bintara polri di Polda Kalteng maka, peneliti melihat dari 2 sisi yakni sarana dan prasarana dan kualitas sumber daya manusianya. Hal ini juga merujuk pada pendapat Van Meter dan Van Horn (Agustino, 20|4:|4|-|49) Keberhasilan pada dukungan sarana dan prasarana dan sangat tergantung dari kemampuan memanfaatkan sumberdaya yang tersedia.

\section{Sarana dan prasarana}

Sarana dan Prasarana atau fasilitas fisik merupakan faktor penting, tanpa adanya fasilitas yang pendukung (sarana dan prasarana) maka kegiatan atau program tersebut tidak akan berhasil. Dari sisi sarana dan prasarana rekrutmen bintara polri di Polda Kalteng masih ada kekurangan dan keterbatasan.

Hal ini karena masih ada beberapa tahapan seleksi yang memerlukan sarana dan prasarana pendukung yang lebih baik lagi dalam menunjang pelaksanaan dilapangan sehingga kepercayaan peserta dan masyarakat semakin baik dalam proses tahapan seleksi rekrutmen anggota Polri di Polda Kalteng. Seperti halnya saat seleksi menggunakan Computer Assisted Test (CAT) pada tahap pemeriksaan psikologi maupun ujian akademik. Walaupun CAT sudah dilaksanakan tapi dengan jumlah calon peserta yang banyak, maka sarana dan prasarana harus bergantian bahkan harus tes di berbagai tempat seperti peminjaman sekolah SMA/SMK.

Disisi lain, karena sistem Computer Assisted Test (CAT) yang dilakukan serentak menggunakan online. Ada masalah jaringan yang terkadang menghambat pelaksanaan atau penundaaan tes Computer Assisted Test (CAT) sampai malam hari. Hal ini diungkapkan oleh salah peserta seleksi :

"Kami seleksi di salah satu SMA di Palangka Raya untuk Computer Assisted Test (CAT) sampai malam hari karena ada kendala sarana dan parasarana dan jaringan sehingga harus menunggu". 


\section{Kualitas Sumber Daya Manusia (SDM)}

Sumber Daya Manusia merupakan sumberdaya yang terpenting dalam menentukan suatu keberhasilan proses pelaksanaan kegiatan atau program. Hal ini mengingat sumberdaya utama dalam kegiatan/program adalah pelaksana, kegagalan yang sering terjadi dalam pelaksanaannya salah satunya disebabkan oleh karena sumber daya manusia yang tidak mencukupi, memadai atau tidak kompeten dibidangnya.

Dalam hal kualitas sumber daya manusia pada pelaksanaan rekrutemen bintara polri di Polda Kalteng terdapat beberapa kendala yaitu :

I. SDM Polri di Polda Kalteng dalam pelaksanaan rekrutmen Bintara Polri diemban oleh fungsi pada Biro SDM Polda Kalteng yaitu Subbagdiapers Bagdalpers Biro SDM Polda Kalteng dengan personel sebanyak 5 orang terdiri dari I (satu) Pamen, I (satu) pama, 2 (dua) Bintara dan I (satu) PNS dan pada pelaksanaan kegiatan rekrutmen melibatkan personel Biro SDM Polda Kalteng pada bag dan subbag lainnya serta melibatkan personel anggota Polri dan PNS Satker dan Satwil yang ditunjuk sebagai Tim Kepanitiaan serta menunjuk pihak eksternal yang dilibatkan dalam kegiatan seleksi.

2. Kendala yang dihadapi adalah kurangnya pemahaman personel dilapangan yang mampu mengawaki tugas secara detail dan terkontrol sehingga masih banyak ditemukan kelalaian dan kesalahan dalam pelaksanaan tugasnya.

\section{KESIMPULAN}

Mekanisme yang selama ini dilaksanakan dalam rekrutmen Bintara Polri Polda Kalteng sudah melalui tahapan yang ditetapkan dari Panitia Pusat/Mabes Polri namun dalam pelaksanaannya masih kurang optimal karena adanya beberapa kendala pada setiap rangkaian tahapan seleksi antara lain :
I) Masih kurangnya rasa peduli dari personel Polri untuk menyosialisasikan/menyampaikan informasi rekrutmen Bintara Polri kepada masyarakat sehingga terkesan yang hanya dibebankan kepada personel SDM.

2) Kurangnya sosialisasi tata cara pendaftaran online serta kurang tersedianya jaringan internet pada daerah pelosok sehingga pendaftar lebih banyak datang ke Polres untuk mendaftar secara online melalui operator pendaftaran di Polres.

3) Belum adanya posko pengaduan keluhan baik untuk peserta maupun masyarakat di lingkungan pelaksanaan seleksi atau di Polda Kalteng

4) Kondisi Sumber Daya Manusia pada Subbagdiapers Bagdalpers Biro SDM Polda Kalteng masih keterbatasan dari personel sebanyak 5 orang (satu Pamen, satu pama, dua Bintara dan I satu PNS) hanya dua orang yang sudah mengikuti kejuruan fungsi SDM.

5) Masih keterbatasan sarana dan prasarana yang akan digunakan dalam pelaksanaan Computer Assisted Test (CAT) ujian Akademik maupun pemeriksaan psikologi.

\section{SARAN}

Dalam rangka mengoptimalkan upaya pelaksanaan rekrutmen Bintara Polri yang lebih berkualitas, bersih, transparan, akuntabel dan humanis guna mewujudkan personel Bintara Polri di Polda Kalteng yang profesional, modern dan terpercaya maka dapat disarankan beberapa hal sebagai berikut :

I. Agar pimpinan tingkat pusat dapat membuat standarisasi kriteria minimal untuk kemampuan yang dimiliki oleh personel yang bertugas sebagai Tim penguji/pemeriksa, yang dibarengi dengan pelatihan-pelatihan peningkatan kemampuan personel untuk pelaksana tugas sebagai Tim penguji/pemeriksa tersebut sehingga penguji/ pemeriksa lebih profesional, handal dan dapat 
dipercaya selama melaksanakan tugas sebagai tim penguji /pemeriksa;

2. Perlu dukungan dari pimpinan tingkat pusat terhadap pelaksanaan tugas Kepolisian di kewilayahan hendaknya juga diimbangi dengan peningkatan dukungan sarana, prasarana dan anggaran dalam pelaksanaan tugas, khususnya dalam hal ini berkaitan dengan penyelenggaraan proses seleksi rekrutmen Bintara Polri guna proses dan hasil seleksi yang semakin lebih baik lagi di masa mendatang.

\section{REFERENSI}

Ambarwati, A., 2017. Audit Manajemen Fungsi Sumber Daya Manusia Padapt. Landipo Niaga Raya Kendari. Jurnal Akuntansi

Azam, I., 2016. Pengaruh Rekrutmen Dan Pelatihan Terhadap Kinerja Karyawan Pada Pt. Traktor Nusantara Pekanbaru (Doctoral Dissertation, Universitas Islam Negeri Sultan Syarif Kasim Riau).

Cushway, Barry. 1994. Human Resource Management. Jakarta. PT. Elex Media Komputindo, Kelompok Gramedia.

Dwaa, N. H. D. (2020). Implementasi Affirmative Action Dalam Rekrutmen Dan Seleksi Bintara Polri di Polda Papua 2019. Publikauma: Jurnal Administrasi Publik Universitas Medan Area, 8(1), 40-49.

Fathurrochman, I., 2017. Pengembangan Kompetensi Pegawai Aparatur Sipil Negara (ASN) Sekolah Tinggi Agama Islam Negeri (STAIN) Curup Melalui Metode Pendidikan Dan Pelatihan. Manajer Pendidikan

Febrina, R. (202I). Implementasi Sistem Merit dalam Rekrutmen ASN di Kabupaten Kampar. Journal of Governance Innovation, 3(I), 73-88.

Kartono, Kartini. 2008. Pemimpin dan Kepemimpinan. Jakarta. PT Raja Grafindo Persada.

Khairuddin, H. And Yuliana, Y., 2019. Pengaruh Rekrutmen Dan Penempatan Terhadap Kinerja Pegawai Non ASN Di Rumah Sakit Umum Daerah Puri Husada Tembilahan. Jurnal Analisis Manajemen,

Pane, S.G., 2019. Pengaruh Rekrutmen Pegawai dan Penempatan Pegawai Terhadap Kinerja Pegawai pada PT. Pelabuhan Indonesil (Persero). Tijarah: Jurnal Ekonomi dan Bisnis.

Pradana, D. R. (2020). Implementasi Rekruitmen Bintara Polri Di Wilayah Kepolisan Resort Banyumas Berdasarkan Undang-Undang Nomor 2
Tahun 2002 Tentang Kepolisian Negara Republik Indonesia. Jurnal Idea Hukum, 6(I).

Putra, D.P., 2019. Lkp: Rancang Bangun Aplikasi Perekrutan Karyawan Berbasis Website pada PT. Saka Mitra Usaha Surabaya (Doctoral dissertation, Institut Bisnis dan Informatika Stikom Surabaya).

Setiyono, B. (2017). Suatu Tinjauan Tentang Proses Rekrutmen Anggota Polri Polda Sulawesi Tengah Yang Bersih Transparan Akuntabel Dan Humanis (Betah) Ke Arah Kelestarian Governans. Asian Journal Of Environment, History And Heritage, I(I).

Silalahi, Ulber. Asas-Asas Manajemen.20I I. Bandung : PT Refika Aditama

Wiratama, A., \& Prasojo, E. (2019). Merit System dalam Mekanisme Rekrutmen dan Seleksi Bintara Polri. Jurnal Ilmu Kepolisian, I3(2), 12. 